University of Nebraska - Lincoln

DigitalCommons@University of Nebraska - Lincoln

USDA National Wildlife Research Center - Staff Publications
U.S. Department of Agriculture: Animal and Plant Health Inspection Service

February 2000

\title{
Winter Habitat Use and Survival of Female Ring-necked Pheasants (Phasianus colchicus) in Southeastern North Dakota
}

\author{
H. Jeffrey Homan \\ North Dakota State University, Fargo
}

George M. Linz

USDA/APHIS/WS National Wildlife Research Center, george_m_linz@yahoo.com

William J. Bleier

North Dakota State University, Fargo

Follow this and additional works at: https://digitalcommons.unl.edu/icwdm_usdanwrc

Part of the Environmental Sciences Commons

Homan, H. Jeffrey; Linz, George M.; and Bleier, William J., "Winter Habitat Use and Survival of Female Ring-necked Pheasants (Phasianus colchicus) in Southeastern North Dakota" (2000). USDA National Wildlife Research Center - Staff Publications. 508.

https://digitalcommons.unl.edu/icwdm_usdanwrc/508

This Article is brought to you for free and open access by the U.S. Department of Agriculture: Animal and Plant Health Inspection Service at DigitalCommons@University of Nebraska - Lincoln. It has been accepted for inclusion in USDA National Wildlife Research Center - Staff Publications by an authorized administrator of DigitalCommons@University of Nebraska - Lincoln. 
Am. Midl. Nat. 143:463-480

\title{
Winter Habitat Use and Survival of Female Ring-necked Pheasants (Phasianus colchicus) in Southeastern North Dakota
}

\author{
H. JEFFREY HOMAN ${ }^{1}$ \\ Department of Zoology, Stevens Hall, North Dakota State University, Fargo 58105 \\ GEORGE M. LINZ \\ U.S. Department of Agriculture, National Wildlife Research Center, Great Plains Field Station, \\ 2110 Miriam Circle, Suite B, Bismarck, North Dakota 58501 \\ WILLIAM J. BLEIER \\ Department of Zoology, Stevens Hall, North Dakota State University, Fargo 58105
}

\begin{abstract}
From 1992 to 1995 we used radiotelemetry to monitor winter habitat selection and survival of female ring-necked pheasants (Phasianus colchicus) in southeastern North Dakota. We captured 100 birds at nine sites in six study blocks centered on cattail-dominated (Typha spp.) semipermanent wetlands. Pheasants showed nonrandom habitat use at two hierarchical scales. At the second-order scale $\left(23-\mathrm{km}^{2}\right.$ blocks) semipermanent wetlands were preferred during two winters in which habitat selection could be assessed (1992-1993 and 1994-1995). An additional second-order preference for grass-covered uplands was shown during the mild 1994-1995 winter. At the third-order scale (home-range) pheasants preferred the edges of wetlands in 1992-1993 and 1994-1995. The central portions of wetlands were preferred in 1992-1993 and used proportionately in 1994-1995. Seasonal wetlands were avoided at the third order scale during 1992-1993 and 1994-1995. The average winter survival rate was 0.41 , with rates ranging from $0.04-0.86$ and differing significantly among winters. Survival was lower during early winter and midwinter periods for birds weighing less than $1090 \mathrm{~g}$ and for birds captured in semipermanent wetlands under private ownership. A $1 \mathrm{C}$ increase in the mean weekly maximum temperature decreased the probability of death by 0.06 and a $2.5 \mathrm{~cm}$ increase in new snow raised the probability of death by 0.08 .
\end{abstract}

\section{INTRODUCTION}

Wetlands that are overgrown with dense monotypic stands of cattail (Typha spp.) have lower biodiversity, altered ecological function and often concentrate overabundant bird species (Weller, 1975; Harris et al., 1983; Kantrud, 1986; Linz et al., 1996). In the northern Great Plains wetland managers have used cattail management to reduce dense stands of cattail and return wetlands to their former mosaics of open water and sparse stands of emergents (Kantrud, 1986; Payne, 1992). However, cattail management may affect wintering ring-necked pheasants (Phasianus colchicus), which often use dense cattail for thermal protection and cover (Trautman, 1982; Gatti et al., 1989; Perkins et al., 1997; Gabbert et al., 1999). The impetus for our research was the concern over the potential impacts of intensive cattail management with Rodeo ${ }^{\varpi}$ herbicide (glyphosate). For example, 14,400 ha of wetlands in North Dakota have been treated with aerially applied Rodeo since 1991 (Homan et al., 1999). Sprayings continue in North Dakota at 2600 ha/y. Although this represents only a small portion of North Dakota's total wetland area, the criteria used to select wetlands for

\footnotetext{
${ }^{1}$ Present address: U.S. Department of Agriculture, Great Plains Filed Station, 2110 Miriam Circle,
} Suite B, Bismarck, North Dakota 58501-2502 
treatment $(>70 \%$ cattail cover and wetland area $>5$ ha) could potentially cause a rapid and extensive loss of cattail cover in larger wetlands.

Pheasants respond differently to local habitat availabilities and climatic conditions, and regional data on habitat use is not widely applicable (Penrod and Hill, 1985; Gatti et al., 1989). We radiotagged 100 female pheasants in southeastern North Dakota and followed them during three winters (1 December to $20 \mathrm{March}$ ) from 1992-1995. The objectives of our study were to establish baseline measurements of wintering behavior and survival. These data will serve as a reference for assessing and mitigating the potential impacts of cattail management on pheasants. Comparative evidence, through a treatment vs. reference study design, could not be acquired by us because numerous wetlands throughout our study area were inundated by rains that raised water levels and 'drowned' cattail in the deeper wetlands in the summer of 1993-1994. Therefore, our study was descriptive research of pheasant behavior during winters in a wet climatic cycle. Important and useful information can be garnered from descriptive 'natural' research (Ratti and Garton, 1994; Gabbert et al., 1999) and resource agencies throughout the Prairie Region may find this information useful for managing pheasant populations.

\section{MethoDs}

Study area.-Our study was conducted in the Southern Drift Plain of southeastern North Dakota where numerous wetlands are interspersed among croplands (Stewart and Kantrud, 1971). Formerly mid- and tallgrass prairie, most of this flat and rolling morainal land is now cropland and pasture. Linear arrays of shrubs and trees (shelterbelts) have been planted throughout the region to reduce climatic effects on croplands and rural residences. The climate is midcontinental with cold winters and warm summers. The average dates of first and last frosts are 20 September and 18 May, respectively. From December to March daily temperatures in southeastern North Dakota average $-9 \mathrm{C}$, with the lowest monthly average occurring in January $(-14 \mathrm{C})$ and the highest in March $(-4 \mathrm{C})$. On average, $47 \mathrm{~d}$ each winter have temperatures $\leq-17 \mathrm{C}$ and approximately $40 \mathrm{~d}$ each winter have snow depths $>15 \mathrm{~cm}$. Annual snowfall in southeastern North Dakota is $81 \mathrm{~cm}$ (Jensen, 1972).

For our three winter seasons 1992-1995, respectively, the study area had 54, 57 and $42 \mathrm{~d}$ $\leq-17 \mathrm{C} ; 68,110$ and $56 \mathrm{~d}$ with snow depths $\geq 15 \mathrm{~cm}$; and 19,99 and $13 \mathrm{~d}$ with snow depths $\geq 30 \mathrm{~cm}$. Snowfall was above 30-y averages for each of the three winters, totaling 103, 197 and $117 \mathrm{~cm}$, respectively. In 1993-1994 heavy snows accumulated in late November when the study area received $77 \mathrm{~cm}$ in one storm. The winter of 1993-1994 was the most severe with maximum and minimum temperatures below 30 -y averages and snowfall $143 \%$ above the 30-y average (Table 1). In 1994-1995 7 of $13 \mathrm{~d}$ with snow depths $\geq 30 \mathrm{~cm}$ occurred in mid-March, near the end of the winter. The 1994-1995 winter was the warmest of the three winters with maximum and minimum daily temperatures above 30 -y averages. Weather data were collected from the National Oceanic and Atmospheric Administration weather station in LaMoure, North Dakota, $58 \mathrm{~km}$ from the farthest study block.

Capture and radiotelemetry.-We randomly selected eight study blocks consisting of $3 \times$ 3 arrays of General Land Office sections $(1.6 \mathrm{~km} \times 1.6 \mathrm{~km})$ with a $10-60$ ha cattail-dominated semipermanent wetland within the center section of each study block (total area per block $=23 \mathrm{~km}^{2}$ ). Distances between study block centers ranged from $10-53 \mathrm{~km}$. All habitats in the eight study blocks were searched for pheasants after the first measurable snowfall. We placed walk-in traps baited with ear corn at high-use sites as determined by flush counts and track densities. Excepting the mild and dry winter of 1994-1995, when trapping was delayed until late December and early January, trapping started in late November and early December. All captured pheasants were banded, sexed, aged and weighed to the nearest $5 \mathrm{~g}$. 
TABLE 1.-Temperature and precipitation variables (departures from monthly 30-y averages) recorded at the NOAA weather station in LaMoure, North Dakota, during a 3-y study (1992-1995) on the winter (1 December-20 March) ecology of female ring-necked pheasants

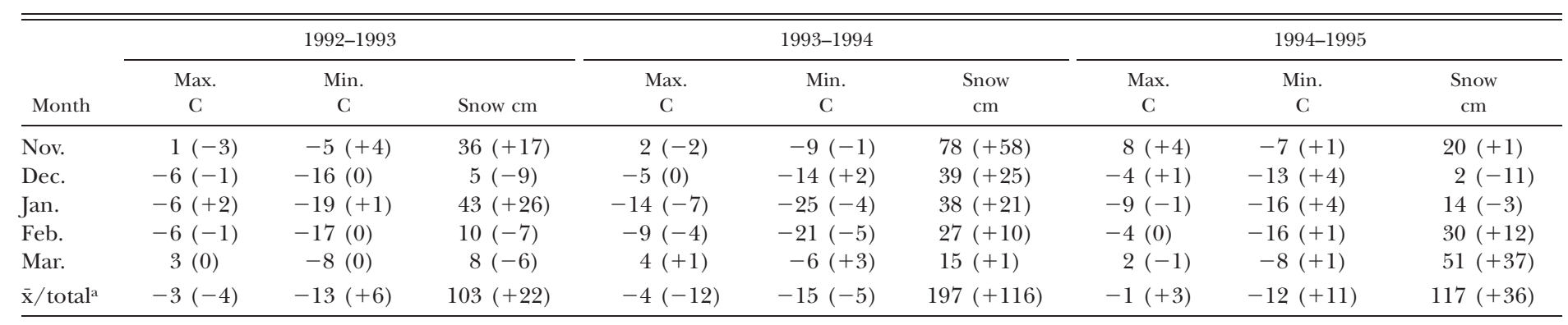

a Numbers in parentheses represent the cumulative departures from 30 -y averages summed over months 
We used the shaft diameter of the innermost (proximal) primary feather to classify females as adults or juveniles (Wishart, 1969; Greenburg et al., 1972; Perkins et al., 1997; Schmitz and Clark, 1999). The study of females is emphasized in pheasant research because females are reproductively successful even at low male: female sex ratios (Trautman, 1982).

We radiotagged all captured females with 12-g battery-powered transmitters (Advanced Telemetry Systems, Isanti, Minnesota) secured by a 3-g necklace (Kenward, 1987; Marcstrom et al., 1989). Body mass of captured females ranged from 800-1400 g, with the transmitter and necklace attachment representing $<2 \%$ of body mass. Data collection was delayed 1 wk after tagging to allow resumption of normal behavior and activities (White and Garrott, 1990). We attempted to relocate the birds 2-3 times per wk using two mobile null-peak receiving units consisting of roof-mounted, horizontal, dual yagi antenna. The study area was delineated by well-defined field margins and a north-south/east-west, $1.6 \mathrm{~km}$ road grid, allowing the precise and accurate alignment of our mobile receiving stations $\leq 0.8 \mathrm{~km}$ from the transmitters. We used Universal Transverse Mercator coordinates to define locations. The methods of Lee et al. (1985) were used to estimate the precision of the receiving system. We used the Andrews estimator with $\geq 3$ bearings to locate transmitters (PC program TRIANG: White and Garrott, 1984). The quality of each radiolocation with $\geq 4$ bearings was judged with chi-square tests using the null hypothesis that all bearings emanated from the same location (White and Garrott, 1990; McNay et al., 1994). If the null hypothesis was rejected $(\alpha=0.05)$ we discarded the bearing contributing the greatest proportion of the $\chi^{2}$-value. We used $\alpha=0.05$ to avoid overestimating the precision of our locations.

During the 1992-1993 winter we located radio-tagged birds alternating between day (1 $\mathrm{h}$ after sunrise $-1 \mathrm{~h}$ before sunset) and night periods ( $1 \mathrm{~h}$ after sunset $-2400 \mathrm{~h}$ ). Quantitative data on winter habitat use of roosting pheasants are sparse. We focused on this aspect of behavior for the latter two winters of the study and made night locations only. Each relocation was separated by $\geq 24 \mathrm{~h}$, enough time for radio-tagged birds to move anywhere within their winter home range and thus achieve independence between locations (Swihart and Slade, 1985; Lair, 1987; McNay et al., 1994; Otis and White, 1999). The average time between successive usable radiolocations (95\% confidence error ellipses $\leq 1$ ha) per bird was about $3 \mathrm{~d}$. Closer observations were made with hand-held receiving units for birds that were consistently inactive or continued to have unusual locations. The midpoint between the date last known alive and the date known dead was treated as the date of death. We used the guidelines of Dumke and Pils (1973) to classify types of predation.

Home range and movements.-The PC program CALHOME (Kie et al., 1996) was used to calculate $100 \%$ minimum convex home-range polygons (MCP) (Mohr, 1947; Schmitz and Clark, 1999) and the mean linear distance between consecutive radiolocations (DBL). The areal extent of individual MCPs plotted against the number of radiolocations showed independence at 10 locations $\left(\mathrm{r}^{2}=0.05 ; F=1.06\right.$; df 1,$\left.20 ; \mathrm{P}=0.32\right)$. Thus, individual homerange estimates were made only on birds with $\geq 10$ locations. Aggregate MCPs were calculated using the combined radiolocations of all individuals pooled by capture site (Gates and Hale, 1974; Whiteside and Guthery, 1983). Because of small sample sizes, home-range analyses could not be made in 1993-1994. We used Wilcoxon two-sample tests to assess the effects of age class on MCP and DBL variables. Spearman's correlation coefficients were used to determine the presence of simple correlations between mass and DBL.

Habitat use.-Digital images of General Land Office Sections were created by scanning 35-mm, false-color, infrared slides into a geographic information system (Map and Image Processing System, MicroImages Incorporated, Lincoln, Nebraska). The slides were taken horizontally at $3000 \mathrm{~m}$ altitude during late August of each year of the study. We used groundtruthed information and definitive color-infrared signatures to identify vegetation types 
within each General Land Office Section. The vegetation was assigned to one of the following eight habitat types: Cropland, Upland, Class III wetland, Class IV wetland, Transportation Easement, Pasture, Farmstead (with associated shelterbelts) and Shelterbelt. Uplands were defined as habitats with residual grassy cover (e.g., Conservation Reserve Program lands and idled areas surrounding wetlands). Class III wetlands were seasonal wetlands, whose deeper central portions are dry usually by early to mid-summer (see classification system of Stewart and Kantrud, 1971). Class IV wetlands were semipermanent wetlands that maintain surface water in their central portions through spring and summer and frequently throughout the year. Coarse grasses (e.g., Scolochloa festucacea) and sedges (e.g., Carex spp.) are characteristic vegetation associated with Class III wetlands; whereas emergents, such as cattail and bulrush (Scirpus spp.), characterize Class IV wetlands. We used a planimeter within the geographic information system to determine habitat availabilities in the General Land Office Sections. Only minor changes in field borders occurred and availability of habitats in the study blocks remained the same during our 3-y study. Wetland categories and cover were obtained from the National Wetlands Inventory database and imported as vectors into the geographic information system and overlayed on the digital images.

Coordinates from the radiolocations were imported into the geographic information system and overlayed on the digital images (cell resolution $=1 \mathrm{~m}^{2}$ ) of the General Land Office Sections. Habitat use was analyzed at second- and third-order levels of selection (Johnson, 1980). Selection is defined as the disproportionate use of resources compared to availability. Second-order selection occurs when individuals or social groups determine their home range from within the species' geographical range (defined as first-order selection); third-order selection pertains to the use of habitats within the home range. For the assessment of second-order selection we compared the mean proportions of habitats within the aggregate MCPs against habitat availabilities averaged across study blocks. Third-order selection compared the mean proportions of classified radiolocations against mean proportions of habitat availabilities within the aggregate MCPs. At the third-order level we created a 'Boundary' habitat to compare use of the wetland-upland interface with use of the wetland's central area (termed Basin habitat). The boundary consisted of a 100-m zone created by the geographic information system. The zone was centered on the wetlandupland interface and was split into a 50-m interior wetland zone and a 50-m exterior upland zone. The 100-m zone was used to ensure the accuracy of classified locations recorded near the wetland-upland interface (see White and Garrott, 1990).

Chi-square statistics were used to test the null hypothesis that pheasants selected habitats in proportion to availabilities at second- and third-order habitat levels. If the null hypotheses were rejected $(\propto 0.10)$, habitat preference was measured with $90 \%$ Bonferroni confidence intervals placed on use proportions (Neu et al., 1974; Byers et al., 1984; Thomas and Taylor, 1990; McClean et al., 1998). We used $\alpha=0.10$ because of the conservative nature of the Bonferroni $z$-statistic when making comparisons among multiple habitats; furthermore, we wanted to reduce Type II errors (accepting false null hypotheses) that frequently occur when analyzing data from field research, which typically has uncontrolled experimental settings, large population variances and small sample sizes because of limited funds and manpower (Tacha et al., 1982; Alldredge and Ratti, 1986; Thomas and Taylor, 1990). To achieve adequate expected cell values for the chi-square tests, Pasture and Transportation Easements were pooled into the 'Other' habitat category and Farmstead habitat was pooled into the Shelterbelt category (Roscoe and Byars, 1971; Alldredge and Ratti, 1986). The relatively small number of radiolocations per bird and the approximate equality in the number of locations per bird, combined with a similarity in habitat use among individuals within 
TABLE 2.-Individual ${ }^{\mathrm{a}}$ and aggregate minimum convex polygon (100\% MCP) estimates for female ring-necked pheasants captured and radiotagged in southeastern North Dakota during the 1992-1993 and 1994-1995 winters (1 December-20 March)

\begin{tabular}{|c|c|c|c|c|}
\hline \multirow[b]{2}{*}{ Winter } & \multirow[b]{2}{*}{ Age class } & \multirow[b]{2}{*}{$\mathrm{n}$} & \multicolumn{2}{|c|}{$100 \%$ MCP (ha) } \\
\hline & & & Median & Range \\
\hline \multicolumn{5}{|l|}{ 1992-1993 b } \\
\hline \multirow{2}{*}{ Individual } & Adult & 7 & 10 & $4-16$ \\
\hline & Juvenile & 5 & 9 & $5-17$ \\
\hline Aggregate $^{c}$ & - & 33 & 55 & 26-109 \\
\hline \multicolumn{5}{|l|}{$1994-1995^{\mathrm{d}}$} \\
\hline \multirow[t]{2}{*}{ Individual } & Adult & 5 & 23 & $14-86$ \\
\hline & Juvenile & 5 & 24 & $5-55$ \\
\hline Aggregate $^{e}$ & - & 13 & 73 & $19-113$ \\
\hline
\end{tabular}

a Data are missing for 1993-1994 because of small sample sizes. Locations were made day and night in 1992-1993 and night only in 1994-1995. Only birds with $\geq 10$ locations were used when calculating individual MCPs

${ }^{\mathrm{b}}$ No age class difference was detected in 1992-1993 $(z=0.16, \mathrm{n}=12, \mathrm{P}=0.87)$

${ }^{c}$ All radiolocations on all birds within capture sites (four capture sites, 17 adults, 16 juveniles)

${ }^{\mathrm{d}}$ No age class difference was detected in 1994-1995 $(z=0.21, \mathrm{n}=10, \mathrm{P}=0.83)$. MCPs pooled by age class were smaller in 1992-1993 $(z=2.57, \mathrm{n}=22, \mathrm{P}=0.01)$ than 1994-1995

${ }^{\mathrm{e}}$ Five capture sites (six adults, seven juveniles). No difference was detected in size of aggregate MCPs between $1992-1993$ and $1994-1995(z=0.14, \mathrm{n}=9, \mathrm{P}=0.88)$

capture sites, allowed for analysis of selection based on pooled radiolocations within capture site within year (Hill and Ridley, 1987; Design 2: Thomas and Taylor, 1990; White and Garrott, 1990; Schooley, 1994). Habitat selection in the 1992-1993 winter was analyzed using day and night locations pooled. Habitat use was not analyzed in 1993-1994 because of high mortality in the radio-tagged group (only 5 of 37 survived $>4$ wk after tagging and only eight relocations qualified).

Survivorship.-Survival probabilities were estimated with the product-limit method using staggered entry (Kaplan and Meier, 1958; Pollock et al., 1989). Data were included up until the last date tracked for birds missing before the end of the study period. Log-rank tests were used to compare survivorship functions between (1) years, (2) age classes, (3) weight classes [above and below the mean mass $(\overline{\mathrm{x}}=1090 \mathrm{~g})$ of birds surviving $>7 \mathrm{~d}$ ] and (4) land ownership classes [public and private]. Log-rank tests and Kaplan-Meier estimates were calculated with SAS code modified from White and Garrott (1990).

Before constructing the winter survival model we used ANOVAs to eliminate nonsignificant $(\mathrm{P}>0.10)$ covariates (Perkins et al., 1997; Riley et al., 1998). The natural log of the failure time $\left(T_{i}\right)$ was the dependent variable. The independent variables used in the ANOVA screening were the proportions of Cropland, Upland and Class IV wetland in the General Land Office Section of the capture site; weight; age class; DBL; and the following climatic variables averaged for $7 \mathrm{~d}$ before death or the last date tracked: minimum daily temperature, maximum daily temperature, snowfall and snow depth. We used PROC PHREG with the /Entry and /Score options to evaluate models and estimate proportional hazard coefficients of survival covariates (Cox, 1972; Allison, 1995; Luukkonen et al., 1997; SAS Institute, 1997). Year effects on research-related mortality (defined as birds living $\leq 7 \mathrm{~d}$ after tagging) were 
TABLE 3.-Linear distance between consecutive locations ${ }^{\mathrm{a}}$ (DBL) of female ring-necked pheasants captured and radiotagged in southeastern North Dakota during the 1992-1993 and 1994-1995 winters (1 December-20 March)

\begin{tabular}{clrrr}
\hline \hline \multirow{2}{*}{ Winter } & & & \multicolumn{2}{c}{ DBL $(\mathrm{m})$} \\
\cline { 4 - 5 } $1992-1993^{\mathrm{b}}$ & Age class & $\mathrm{n}$ & Median & \multicolumn{1}{c}{ Range } \\
& Adult & 16 & 153 & $60-629$ \\
& Juvenile & 14 & 192 & $105-942$ \\
$1994-1995^{\mathrm{c}}$ & Pooled & 30 & 156 & $60-942$ \\
& Adult & 6 & 246 & $170-301$ \\
& Juvenile $^{*}$ & 8 & 256 & $144-542$ \\
& Pooled $^{\mathrm{d}}$ & 14 & 247 & $144-542$ \\
\hline
\end{tabular}

a Birds with $\geq 2$ locations

${ }^{\mathrm{b}}$ No age class difference was detected in 1992-1993 $(z=1.56, \mathrm{n}=30, \mathrm{P}=0.12)$

${ }^{c}$ No age class difference was detected in 1994-1995 $(z=0.32, \mathrm{n}=14, \mathrm{P}=0.75)$

${ }^{\mathrm{d}}$ DBL was shorter in 1992-1993 than 1994-1995 $(z=2.26, \mathrm{n}=44, \mathrm{P}=0.02)$

analyzed with G-tests (Sokal and Rolf, 1981). All statistical tests were performed with PCSAS (SAS Institute, 1988).

\section{RESULTS}

Capture and radiotelemetry.-We radiotagged 100 birds at nine capture sites in six study blocks. Most birds were captured in December (55\%) and January (25\%). Seventy-three birds $\left(\mathrm{n}_{1992-93}=39, \mathrm{n}_{1993-94}=20\right.$ and $\left.\mathrm{n}_{1994-95}=14\right)$ provided data after the 7-d adjustment period. Of this sample, 36 were adults $\left(\overline{\mathrm{x}}_{\mathrm{wt} .}=1152 \mathrm{~g}\right.$, SD $\left.=108.4\right)$ and 37 were juveniles $\left(\overline{\mathrm{x}}_{\mathrm{wt} .}=1028 \mathrm{~g}, \mathrm{SD}=90.1\right)$.

Receiving system precision was $1.9^{\circ}(\mathrm{n}=210)$ with a mean distance of $21 \mathrm{~m}(\mathrm{SD}=14.7$, $n=50$ ) between estimated and actual locations. The average $95 \%$ confidence error ellipse generated during precision testing was 0.60 ha. For all locations pooled over the 3-y study the average distance from receiving sites to transmitters was $585 \mathrm{~m}(\mathrm{SD}=203.9, \mathrm{n}=503)$ with a $95 \%$ confidence error ellipse of 0.4 ha $(\mathrm{SD}=0.24) ; 68 \%$ of the ellipse areas were $\leq 0.5$ ha. Patch size of the habitats in the aggregate MCPs averaged 3.1 ha $(\mathrm{SD}=0.9)$.

Home range and movements.-No age-class differences were detected in MCP size in 19921993 and 1994-1995 (Table 2). After pooling age classes MCPs of individuals were smaller in 1992-1993 with less variability $(F=36.9$; df 9,11 ; $\mathrm{P}<0.001)$ than individual MCPs in 1994-1995. Aggregate MCPs were statistically equal in size between 1992-1993 and 19941995. No age-class differences in DBL were observed in either 1992-1993 or 1994-1995 (Table 3); however, variation was greater for juvenile DBL in both 1992-1993 ( $F=3.5$; df $13,15 ; \mathrm{P}=0.01)$ and $1994-1995(F=8.0 ; \mathrm{df} 7,5 ; \mathrm{P}=0.02)$. Pooled by age class, DBLs were shorter in 1992-1993 than in 1994-1995; DBL variances between years were heterogeneous $(F=4.0$; df 29, 13; $\mathrm{P}=0.005)$. No correlations were observed between mass and DBL in either 1992-1993 $\left(\mathrm{r}^{2}=0.07, \mathrm{P}=0.16\right)$ or $1994-1995\left(\mathrm{r}^{2}=0.001, \mathrm{P}=0.91\right)$.

Habitat selection.-We used 303 radiolocations in 1992-1993 (four capture sites, $\mathrm{n}=33$ birds) and 200 in 1994-1995 (five sites, $n=14$ birds). We discarded the 1993-1994 data set because only one bird survived, thus yielding an inadequate sample for that winter. Sampling effort by month was spread evenly between winters with $20 \%$ of the radiolocations in January, $42 \%$ in February and 35\% in March. Seven percent of the radiolocations were collected in December 1992; none were collected in December 1994. 


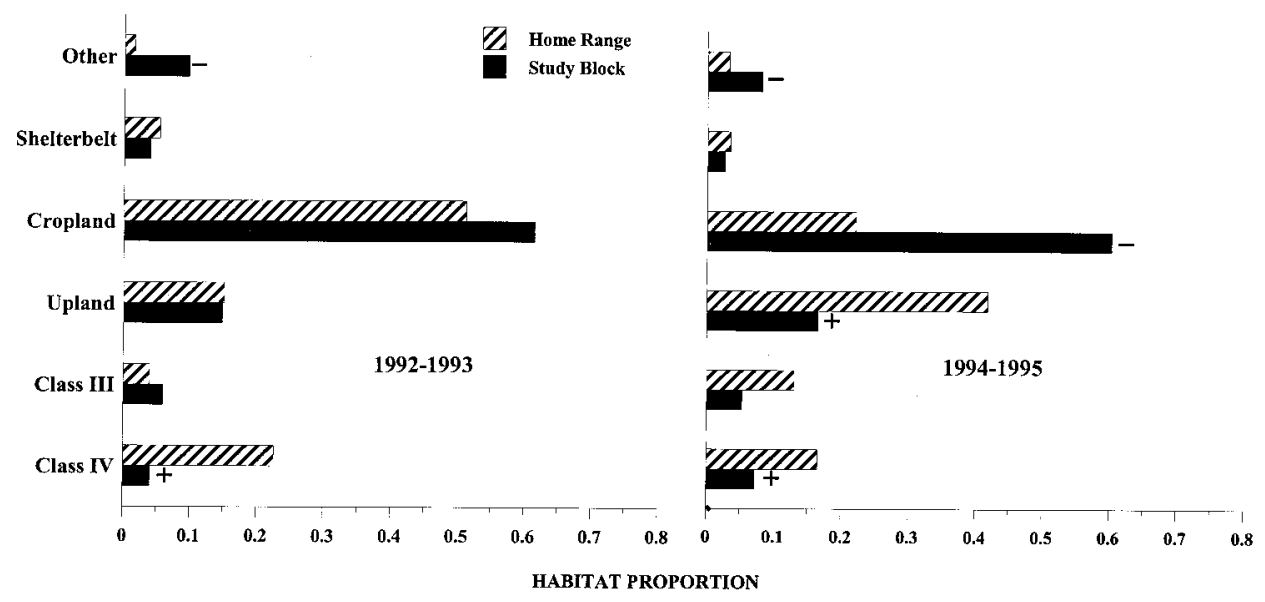

FIG. 1.-Second-order habitat use and selection by wintering female ring-necked pheasants in 19921993 and 1994-1995. Symbols indicate significant $(\mathrm{P} \leq 0.10)$ preference '+' and avoidance ' - '. No symbol indicates use according to availability

During the 1992-1993 winter day and night habitat use differed for Class IV wetland $\left(\chi^{2}=19.2\right.$, df $\left.1, \mathrm{P}<0.001\right)$, Upland $\left(\chi^{2}=4.1\right.$, df $\left.1, \mathrm{P}=0.04\right)$ and Cropland $\left(\chi^{2}=12.4\right.$, df $1, \mathrm{P}<0.001)$. Use of Class IV wetlands was proportionately greater at night $(0.84)$ than day (0.59); whereas day use of Upland and Cropland was proportionately greater $(0.20$ and 0.14 , respectively) than night use (0.10 and 0.01 , respectively). Sample sizes were too small to test for differences in day and night use in the remaining habitat categories. A comparison of night locations between 1992-1993 and 1994-1995 indicated that Class IV wetlands were used less frequently at night in 1994-1995 (0.34) than in 1992-1993 $\left(0.84 ; \chi^{2}=54.4\right.$, df $1, \mathrm{P}<0.001)$; whereas nighttime use of Uplands was greater in 1994-1995 (0.53) than in 1992-1993 $\left(0.10 ; \chi^{2}=75.2\right.$, df $\left.1, \mathrm{P}<0.001\right)$.

Use of second-order habitats was not random in either 1992-1993 ( $\chi^{2}=92.3$, df 5 , $\mathrm{P}<$ $0.0001)$ or $1994-1995\left(\chi^{2}=89.8\right.$, df $\left.5, \mathrm{P}<0.0001\right)$. Class IV wetlands were preferred during both 1992-1993 and 1994-1995 being selected more frequently than availability would indicate (Fig. 1). Uplands, used according to second-order availability in 1992-1993, were preferred in 1994-1995. Croplands were used according to their availability in 1992-1993 and were avoided in 1994-1995; 'Other' habitats (second-order availability: 85\% Pasture and $15 \%$ Transportation Easement) were avoided during both winters. With locations pooled between years, Uplands and Class IV wetlands accounted for $85 \%$ of second-order use.

Habitat use at the third-order level was nonrandom during both 1992-1993 ( $\chi^{2}=155.3$, df $7, \mathrm{P}<0.0001)$ and 1994-1995 $\left(\chi^{2}=23.6\right.$, df $\left.6, \mathrm{P}<0.001\right)$. Pheasants preferred Boundary habitat during both winters (Fig. 2); whereas Basin habitat (the central portion of the wetland) was preferred in 1992-1993 only. No third-order preference for Uplands was indicated in either winter. Croplands were used in 1992-1993 (for diurnal activities, such as loafing and feeding) but were used at lower than expected frequencies; Croplands were not used in 1994-1995, when only roosting locations were taken. Class III wetlands were avoided both winters at the third-order level. Shelterbelts were avoided in 1992-1993 but were used proportionately in 1994-1995; 'Other' habitat (consisting of 95\% Transportation 


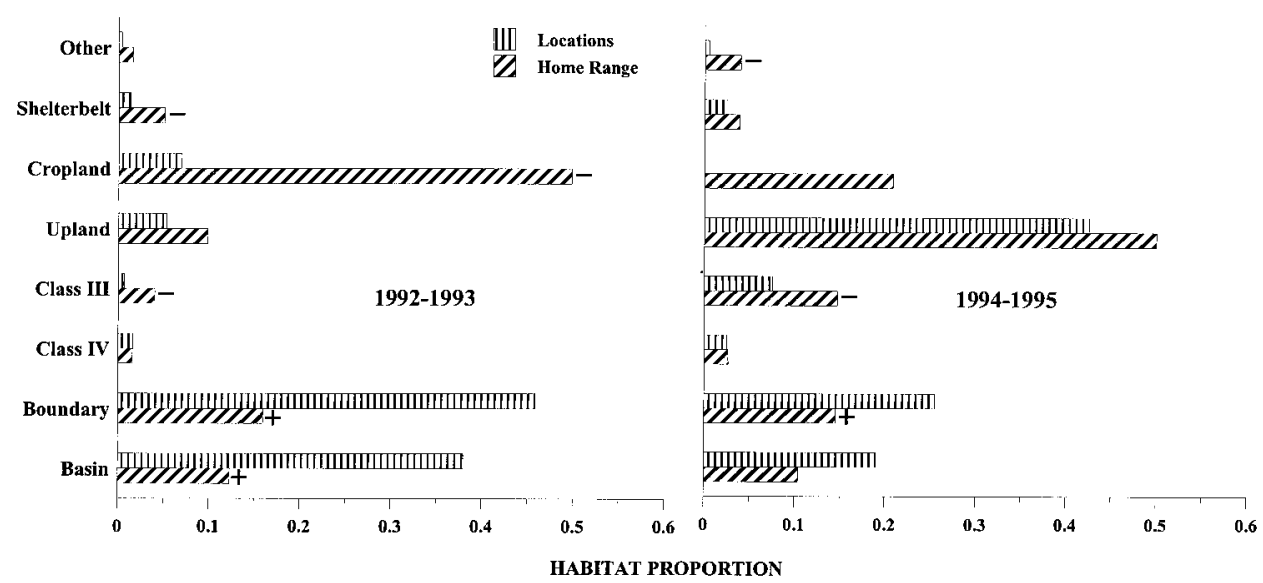

FIG. 2.-Third-order habitat use and selection by wintering female ring-necked pheasants in 19921993 and 1994-1995. Symbols indicate significant $(\mathrm{P} \leq 0.10)$ preference ' + ' and avoidance ' - '. No symbol indicates use according to availability. The 'Class IV' habitat is Class IV wetlands lying outside of the inner wetland buffer

Easement and 15\% Pasture at the third-order) was selected according to its availability in 1992-1993 and avoided in 1994-1995.

In 1992-1993 use of the interior 50-m zone of the wetland boundary (0.59) exceeded use of the exterior zone $\left(0.41 ; \chi^{2}=4.1, \mathrm{df} 1, \mathrm{P}=0.04\right)$ for day and night locations pooled. Use of the interior zone in 1992-1993 was similar $\left(\chi^{2}=1.0\right.$, df $\left.1, \mathrm{P}=0.32\right)$ between day (0.56) and night (0.44); but day use (0.82) exceeded night use $\left(0.18 ; \chi^{2}=22.7\right.$, df $1, \mathrm{P}<$ 0.001) in the exterior zone. In 1994-1995 nighttime use of the exterior zone of the wetland boundary, although greater than use of the interior zone $(0.55$ vs. 0.45$)$, was not significantly different $\left(\chi^{2}=0.3\right.$, df $\left.1, P=0.58\right)$. Nighttime use of the exterior $50-\mathrm{m}$ zone tripled between 1992-1993 (0.18) and 1994-1995 (0.55). In 1992-1993 Cropland (50\%), Boundary (16\%; exterior and interior zones combined) and Basin (12\%) habitats comprised the majority of habitats found in aggregate MCPs. The aggregate MCP in 1994-1995 contained mostly Upland (40\%), Cropland (21\%), Class III wetland (12\%) and Boundary (11\%).

Survivorship.-Average winter survival was 0.41 over three winter seasons. Significant differences existed among all years $\left(S_{1992-1993}=0.33 \pm 0.09, S_{1993-1994}=0.04 \pm 0.03, S_{1994-1995}\right.$ $=0.86 \pm 0.07, \mathrm{P}$ 's $<0.05)$ (Fig. 3). Survival, although higher for adults $(S=0.32 \pm 0.08)$ was statistically similar to juvenile survival $\left(S=0.23 \pm 0.08, \chi^{2}=1.31, \mathrm{P}=0.25\right)$. We detected differences in survivorship functions between two mass categories and two classes of property ownership. Lower early-winter survival rates were observed for radio-tagged birds weighing less than $1090 \mathrm{~g}$ at capture $\left(\chi^{2}=10.49\right.$, df $\left.=1, \mathrm{P}=0.001\right)$ and for birds captured at privately-owned wetlands vs. publicly-owned wetlands $\left(\chi^{2}=25.72\right.$, $\mathrm{df}=1, \mathrm{P}<$ 0.001). The differences between survivorship functions in mass and ownership classes diminished as winter progressed, with survival rates becoming approximately equal by mid February.

On average, dead birds were found within $7 \mathrm{~d}$ of their demise. We knew the fates of 72 of the 73 radio-tagged birds used for the analysis that survived $>7 \mathrm{~d}: 34$ survived (16 adults, 18 juveniles), 38 died (20 adults, 18 juveniles). After excluding missing birds and deaths presumed from research handling (i.e., deaths occurring $\leq 7 \mathrm{~d}$ from the date of tagging), 


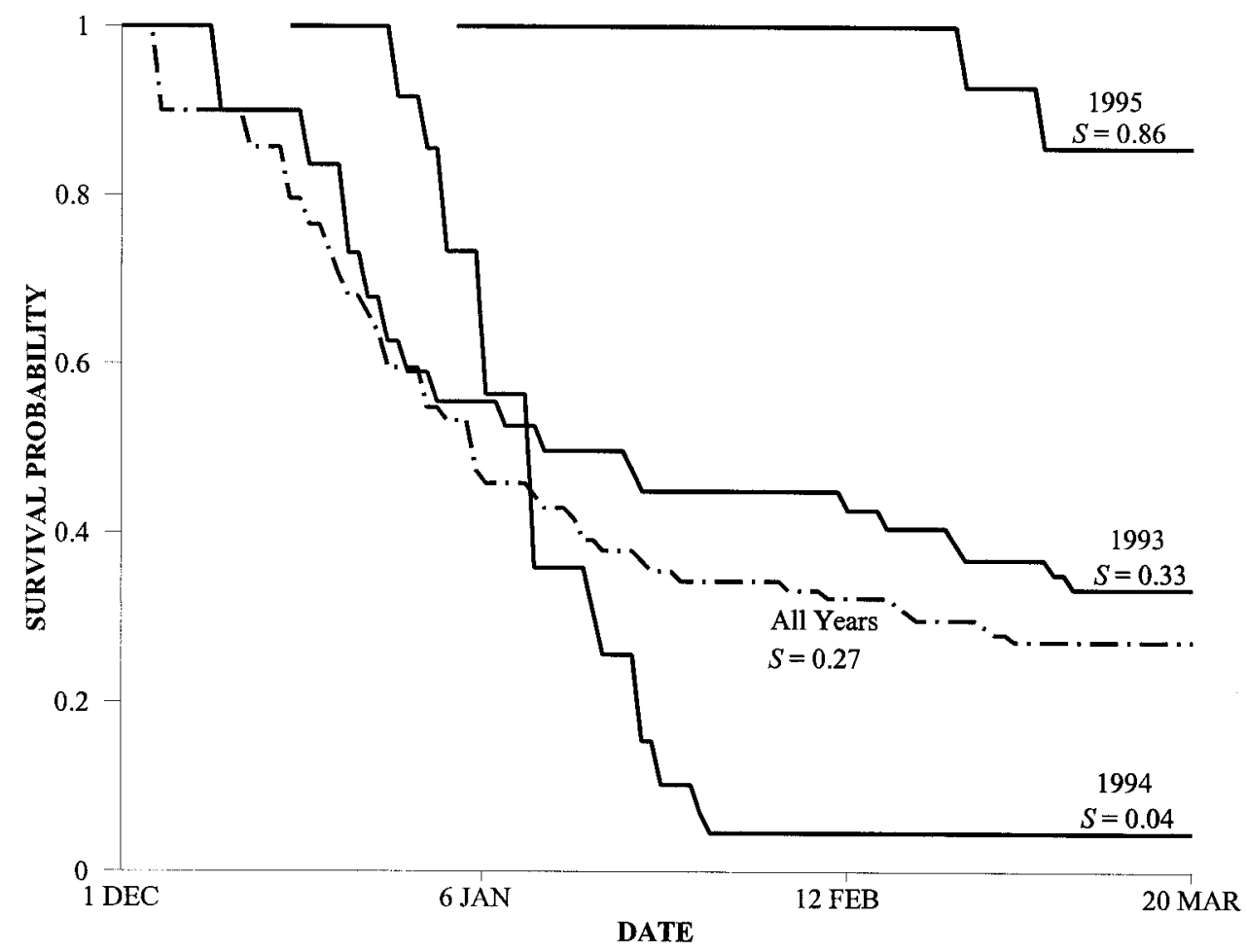

FIG. 3.-Kaplan-Meier survival probabilities for female ring-necked pheasants captured during three winters (1 December-20 March) from 1992-1995 in southeastern North Dakota

predation accounted for $76 \%$ of the mortality (Table 4). Avian predation accounted for $34 \%$ of the mortalities, followed by undetermined predation (27\%). We had 21 researchrelated deaths: eight adults $(\overline{\mathrm{x}} \mathrm{wt} .=1104 \mathrm{~g}, \mathrm{SD}=57.2)$ and 13 juveniles $(\overline{\mathrm{x}} \mathrm{wt} .=990 \mathrm{~g}$, $\mathrm{SD}=109.5)$. Age-class proportions for birds that died from research-related causes did not differ from those surviving $>7 \mathrm{~d}\left(\chi^{2}=0.74\right.$, $\left.\mathrm{df}=1, \mathrm{P}=0.39\right)$. Research-related mortality was significantly greater in 1993-1994 (36\%) than in the other two winters of the study (P range: $0.002-0.04)$ and greater in 1992-1993 (16\%) than 1994-1995 (0\%, P = 0.04). Eight of the 21 birds that died from research handling were found with no apparent internal or external injuries. Mass at time of capture did not influence research-related mortality $(z=$ $1.52, \mathrm{n}=21, \mathrm{P}=0.13)$.

Six of 10 survival covariates passed initial ANOVA screening and were used to model proportional hazards (Table 5). Two of the covariates were habitat variables and four were climatic variables. The six-variable model was significant (likelihood-ratio test: $\chi^{2}=31.46$, $\mathrm{P}<0.0001)$; however, $\beta$ estimates from the six-variable model were not significantly different from zero $(\mathrm{P}>0.20)$, excepting accumulation of new snow (i.e., snow that accumulated $1 \mathrm{wk}$ before death or the last date tracked, $\mathrm{P}=0.09)$. A three-variable model that consisted of maximum daily temperature, accumulation of new snow and proportion of Upland in the General Land Office Section of the capture site had a nearly equal fit $\left(\chi^{2}=31.32, \mathrm{P}\right.$ $<0.0001$ ) to the six-variable model (Table 6 ). In this model maximum daily temperature was significant $(P<0.0001)$, as was the accumulation of new snow $(P=0.10)$. Although 
TABLE 4.-Fates (\%) of 100 female ring-necked pheasants captured during winter (1 December-20 March) 1992-1995 in southeastern North Dakota

\begin{tabular}{|c|c|c|c|c|c|c|c|c|c|c|c|c|c|c|c|c|c|}
\hline \multirow[b]{3}{*}{ Year } & \multirow{2}{*}{\multicolumn{2}{|c|}{ Survived }} & \multirow{2}{*}{\multicolumn{2}{|c|}{ Missinga }} & \multirow{2}{*}{\multicolumn{2}{|c|}{ Research $^{\mathrm{b}}$}} & \multirow{2}{*}{\multicolumn{2}{|c|}{ Collision $^{c}$}} & \multirow{2}{*}{\multicolumn{2}{|c|}{ Unknown $^{\mathrm{d}}$}} & \multicolumn{6}{|c|}{ Predation $^{\mathrm{e}}$} & \multirow[b]{3}{*}{ Total } \\
\hline & & & & & & & & & & & \multicolumn{2}{|c|}{ Undetermined } & \multicolumn{2}{|c|}{ Mammal } & \multicolumn{2}{|c|}{ Raptor } & \\
\hline & $\mathrm{n}$ & $\%$ & $\mathrm{n}$ & $\%$ & $\mathrm{n}$ & $\%$ & $\mathrm{n}$ & $\%$ & $\mathrm{n}$ & $\%$ & $\mathrm{n}$ & $\%$ & $\mathrm{n}$ & $\%$ & $\mathrm{n}$ & $\%$ & \\
\hline 1993-1994 & 1 & 3 & 2 & 5 & 13 & 36 & 2 & 5 & 3 & 8 & 3 & 8 & 3 & 8 & 10 & 27 & 37 \\
\hline 1994-1995 & 12 & 86 & 0 & 0 & 0 & 0 & 0 & 0 & 0 & 0 & 1 & 7 & 1 & 7 & 0 & 0 & 14 \\
\hline Total & 33 & 33 & 5 & 5 & 21 & 21 & 2 & 2 & 8 & 8 & 11 & 11 & 6 & 6 & 14 & 14 & 100 \\
\hline
\end{tabular}

a Birds were declared missing because of radio failure or departure from the study site. Data were used until the last date tracked

All mortality $\leq 7 \mathrm{~d}$ after radiotagging was defined as being caused by research handling. Of the 21 'researched-induced' deaths, seven (33\%) were undetermined predation; eight $(38 \%)$ were unknown; one $(5 \%)$ was mammal; and five $(24 \%)$ were raptor

${ }^{c}$ Intact birds either severely bruised or with broken bones

${ }^{\text {a }}$ Full-bodied birds with no apparent internal or external injuries, death probably from suffocation or starvation

Guidelines for classification described by Dumke and Pils (1973) 
TABLE 5.-Results of one-factor ANOVAs on 10 potential explanatory variables ${ }^{a}$ of survival for wintering female ring-necked pheasants in southeastern North Dakota, 1992-1995

\begin{tabular}{lcccc}
\hline \hline \multicolumn{1}{c}{ Variable } & F & Model df & Error df & P \\
\hline Daily max. temp. $^{\mathrm{b}}$ & 23.40 & 1 & 71 & $<0.0001$ \\
Daily min. temp. & 22.40 & 1 & 71 & $<0.0001$ \\
New snow & 15.86 & 1 & 71 & 0.0002 \\
Depth of snow on ground & 8.16 & 1 & 71 & 0.0056 \\
Upland $^{\mathrm{c}}$ & 4.41 & 1 & 71 & 0.0392 \\
Cropland $^{\mathrm{d}}$ & 3.21 & 1 & 71 & 0.0775 \\
Class IV $^{\mathrm{e}}$ & 0.95 & 1 & 71 & 0.3325 \\
Age class $^{\mathrm{f}}$ & 0.69 & 1 & 71 & 0.4083 \\
$\overline{\mathrm{x}}_{\text {distance }}^{\mathrm{g}}$ & 0.21 & 1 & 42 & 0.6602 \\
Weight & 0.04 & 1 & 70 & 0.8454 \\
\hline
\end{tabular}

a Variables with P-values $\leq 0.10$ were entered into a Cox proportional hazards model

b Weather variables were collected at the National Oceanic and Atmospheric Administration station in LaMoure, North Dakota. They were averaged for the $7 \mathrm{~d}$ prior to date of death or censoring

${ }^{c}$ Proportion of grassland habitat in the General Land Office section of the capture site

d Proportion of cropland habitat in the General Land Office section of the capture site

e Proportion of Class IV wetland habitat in the General Land Office section of the capture site

${ }^{\mathrm{f}}$ Estimated using the proximal primary technique (Wishart, 1969)

g Mean linear distance between consecutive locations

significant in the ANOVA screening, proportion of Upland was not significant in the threevariable model $(\mathrm{P}=0.13)$; its inclusion, however, improved fit over any two-variable model. For every $1 \mathrm{C}$ rise above the average maximum daily temperature the probability of death $[h(t)]$ decreased by 0.06 ; whereas the probability of death increased by 0.08 for every 2.5 $\mathrm{cm}$ of snow accumulation. The minimum daily temperature was also highly significant ( $\mathrm{P}$ $<0.001)$ in the models tested, but it acted antagonistically when combined with maximum daily temperature, which always provided better fit when combined with other covariates of survival.

\section{DISCUSSION}

Habitat selection.-Over three climatically diverse winters in southeastern North Dakota, pheasants showed plasticity in their selection of habitats that was dictated by snow depth and the concomitant loss of cover. Habitat selection followed a sequence that went from idled uplands to large Class IV wetlands to shelterbelts. The selection sequence described above follows that documented for wintering pheasants in Wisconsin (Gates and Hale, 1974), South Dakota (Sather-Blair and Linder, 1980; Gabbert et al., 1999) and Iowa (Perkins et al., 1997). Pheasants form stronger bonds with their upland breeding areas than they do with lowland wintering areas (Gate and Hale, 1974), often remaining in the vicinity of breeding sites until forced to leave by the loss of standing residual cover (Leptich, 1992). Thus, the uplands used by our radio-tagged pheasants throughout the 1994-1995 winter were probably the same as those used the previous spring for breeding. In Wisconsin, pheasants departed from upland habitats and sought refuge in cattail vegetation when snow depths became $\geq 30 \mathrm{~cm}$ (Gates and Hale, 1974; Larsen et al., 1994). In November 1992, 36 $\mathrm{cm}$ of new snow in our study area probably forced pheasants from the upland cover of Conservation Reserve Program fields into cattail cover of large ( $\geq 10$ ha) Class IV wetlands. Snow depths $\geq 38 \mathrm{~cm}$ often cause pheasants to abandon wetland cover and seek emergency 
TABLE 6.-Cox proportional hazards model ${ }^{\text {a }}$ for female ring-necked pheasants radiotagged during winter (1 December-20 March) in southeastern North Dakota, 1992-1995

\begin{tabular}{lrcrrc}
\hline \hline Parameter & $\hat{\beta}$ & $\mathrm{SE}$ & Wald $\chi^{2}$ & $\mathrm{P}$ & Risk ratio \\
\hline Temperature $^{\mathrm{b}}$ & -0.064 & 0.017 & 13.982 & $<0.001$ & 0.938 \\
New snow & 0.080 & 0.048 & 2.766 & 0.096 & 1.084 \\
Upland $^{c}$ & -0.013 & 0.008 & 2.300 & 0.130 & 0.987 \\
\hline
\end{tabular}

${ }^{\mathrm{a}} \chi^{2}=31.3,3 \mathrm{df}, \mathrm{P}<0.0001$

${ }^{\mathrm{b}}$ Maximum daily temperature and new snow accumulations were averaged for the $7 \mathrm{~d}$ prior to date of death or censoring

${ }^{c}$ Proportion of idled land in the General Land Office section of the capture site

shelter in woody habitats (Gatti et al., 1989; Perkins et al., 1997; Gabbert et al., 1999). Snow from a late November 1993 storm followed by an above-average snowfall in December had eliminated most of the wetland cover in our study area by late December. Snow drifting from the uplands into the wetlands further exacerbated the loss of cover in 1993-1994. Field evidence indicated that winter increased use of woody habitats by pheasants. We retrieved seven unscavenged and unpredated carcasses of radio-tagged birds in farmstead shelterbelts $0.8-3.2 \mathrm{~km}$ from their wetland capture sites. The sole radio-tagged survivor of the 1993-1994 winter remained in a multirowed shelterbelt next to a livestock-feeding operation about $1 \mathrm{~km}$ from its wetland capture site. In contrast, pheasants radiotagged in the 1992-1993 and 1994-1995 winters were sedentary, staying near their capture sites and rarely moving $>200 \mathrm{~m}$ between locations. Furthermore, no radio-tagged birds continually roosted in shelterbelts in either 1992-1993 or 1994-1995.

Conservation Reserve Program lands often contain numerous small $(<10$ ha) Class III and Class IV wetlands. In our study pheasants that used Conservation Reserve Program lands generally (but not exclusively) stayed near the embedded wetlands. Thus, wetlands remained the foci of wintering pheasants even during mild winters. Use by pheasants in 1994-1995 of the exterior 50-m wetland zone, which was mostly grassland vegetation, increased as snow depths decreased, contributing to the second-order preference that we observed for Uplands that winter. In South Dakota and Nebraska small wetlands surrounded by grassy buffers were used periodically by wintering pheasants, especially during shallowsnow periods (Sather-Blair and Linder, 1980; Delisle and Savidge, 1997). Substantial buffers of residual grass hold back drifting snow, prolonging the time that smaller wetlands provide adequate winter cover. Warm-season grasses (e.g., Panicum virgatum), rather than coolseason grasses, provide a better winter cover that withstands compression by snow (Larsen et al., 1994; Delisle and Savidge, 1997).

Several studies have reported on differences in movements and home ranges between adult and juvenile pheasants, with juveniles being less settled than adults (e.g., Gates and Hale, 1974; Wooley and Rybarzck, 1981; Gatti et al., 1989). Although we did not detect any statistical age-class differences in median values for either linear-movement or home-range variables, the variation associated with linear movements of juveniles was significantly greater than adult variation. When snow depths restricted habitat availability in 1992-1993 juveniles made linear movements considerably longer $(\overline{\mathrm{x}}=299 \mathrm{~m})$ than those made by adults $(\overline{\mathrm{x}}=183 \mathrm{~m})$. Significant variation between age classes could imply behavioral differences and, when combined with the trend of juveniles towards larger mean values, may signify a behavioral interaction (e.g., competition over resources).

Survivorship.-The average winter survival rate recorded in this study is low (0.41) for 
pheasants, with only Gabbert et al. (1999) in eastern South Dakota reporting a lower average winter survival during a 2-y study $(S=0.32, \mathrm{SD}=0.41$, range: $0.03-0.61)$. Northern pheasant populations often have higher winter mortality rates than birds from more southerly regions. For example, research in Iowa showed average winter survival rates of $0.64(\mathrm{n}=5$ $\mathrm{y}, \mathrm{SD}=0.23$, range: $0.23-0.96)$ (Perkins et al., 1997) and $0.67(\mathrm{n}=3 \mathrm{y}, \mathrm{SD}=0.14$, range: 0.52-0.80) (Riley et al., 1994). The large coefficient of variation (SD/ $\overline{\mathrm{x}} \times 100)$ found in our study (102\%), and that from Gabbert et al. (1999) (128\%), shows that northern winters sporadically impact winter populations, which in turn could affect the annual productivity of pheasants (Jarvis and Simpson, 1978). Winter survival may therefore be the limiting factor on phasianid populations in the northern Great Plains (Carroll, 1990; Riley et al., 1994; Evard, 1996). Winter-related storm losses of 70-90\% have been estimated in Illinois (Warner and David, 1982) and northcentral South Dakota (Trautman, 1982). In South Dakota high winter mortality can be expected from winter storms once every 6 y (Kimball, 1948).

Our proportional hazards model is similar to a log-linear model created for female pheasants in Iowa (Perkins et al., 1997). Temperature variables in both models accounted for $>70 \%$ of the $\chi^{2}$-values; whereas precipitation variables contributed $<14 \%$. In the $1993-1994$ winter the combination of high snowfall and lower-than-average temperatures caused the survival rate to decline by $88 \%$ from our 1992-1993 estimate. Perkins et al. (1997) recorded a decline of $65 \%$ between a mild 1992-1993 winter and a cold 1993-1994 winter in their agriculturally-dominated study area and a $95 \%$ decline in the winter survival rate of pheasants was recorded between two disparate winters in South Dakota (Gabbert et al., 1999). Conversely, when winters are mild and dry survival of wintering pheasants may be very high; in central Missouri a survival rate of 0.95 was recorded during a mild winter (Wilson $e t$ al., 1992).

Predation accounted for $76 \%$ of the mortalities during our study. Avian predation (34\%) was greater than mammalian predation (15\%). In northcentral North Dakota avian predation on gray partridge (Perdix perdix) was the major cause of winter mortality, with little or no evidence of mammalian predation (Carroll, 1990). We speculate that great horned owls (Bubo virginianus) were the main avian predators of pheasants because diurnal raptors were rarely sighted and great horned owls were common in our study area (Stewart, 1975). Nesting great horned owls were thought to be the major avian predators of pheasants at a Colorado study site, accounting for most of the deaths caused by raptors (Snyder, 1985). Elevated rates of avian predation are often correlated with increased snow depth and cover, which causes pheasants to aggregate, depletes vegetative cover and reduces the availability of mammalian prey (Wagner et al., 1965; Dumke and Pils, 1973; Penrod and Hill, 1985).

The differences in survival of pheasants between privately-owned and publicly-owned wetlands may have resulted from two different modes of mortality. The sharp early winter decline in survival at privately owned block-centered wetlands was probably caused by the lack of extensive cover and low food resources; whereas the steady decline in survival during mid- and late winter at publicly owned wetlands may have been caused by avian predators attracted to large trees and multi-rowed shelterbelts that surrounded the public wetlands. Pheasants closely associated with trees incurred higher rates of avian predation in Wisconsin (Petersen, 1979), Colorado (Snyder, 1985) and Maryland (Smith, 1994). Carroll et al. (1995) suggested that the infrequent use of mature shelterbelts by wintering gray partridge in North Dakota was caused by predation from great horned owls, which begin nesting in shelterbelts in North Dakota as early as February (Stewart, 1975).

Management recommendations.-The importance of emergent cover provided by cattail was undeniable during two of the three winters (1992-1993 and 1994-1995). Both winters 
had above-average snow depths; however, timing of the snows was critical in determining habitat use. Upland cover in Conservation Reserve Program lands and small embedded Class IV wetlands with cattail sufficed for wintering pheasants in 1994-1995, when the only major snowfall came in mid March. In contrast, large cattail-dominated wetlands were needed by pheasants throughout the 1992-1993 winter, when cover in the uplands and in small wetlands was diminished because of above-average snowfall in November and early January. In 1993-1994 the cover provided by vegetation in multirowed farmstead shelterbelts and woodlots was all that was left after drifting snow from storms in November and December filled all Class IV wetlands. Pheasant survival that winter plummeted. Game managers need to establish multiple types of cover close together to provide pheasants refuge from the vagaries of unforeseen and unpredictable winter weather in the northern Great Plains. Substantial buffers of stout residual vegetation should be planted around wetlands to allow pheasants to loaf and feed near to their winter roosting sites in wetland basins and to prevent snow from drifting into the wetlands. Shelterbelt and tree plantings should be placed judiciously to prevent pheasants from being disadvantaged by predators. Food plots (e.g., standing corn) adjacent to wintering sites may enhance survival by improving the physical condition of wintering pheasants during deep snow periods (Larsen et al., 1994; Gabbert et al., 1999). Finally, we concur with both Carrol (1990) and Gabbert et al. (1999) that the capturing and handling of game birds during harsh winter periods may cause high rates of research-related mortality. Although this kind of mortality can only be inferred in field studies and is arbitrarily defined by the researchers (e.g., $\leq 7 \mathrm{~d}$ after tagging), the capture and handling of birds in harsh climatic conditions probably exacerbates an already strenuous period in the birds' lives, leaving them more susceptible to death.

Acknowledgments.-We thank J. A. Peterson for his assistance in the field. Helpful comments on the manuscript were provided by M. Avery, L. Flake and D. Mott. We wish to acknowledge the helpful staffs at LaMoure, Sargent, Dickey and Ransom county Agricultural Stabilization and Conservation Service offices. We are indebted to the U.S. Fish and Wildlife Service and the North Dakota Game and Fish Department for granting permission to conduct research on their management areas. We also extend our appreciation to the landowners of southeastern North Dakota for allowing access to their properties. Funding was provided by U.S. Department of Agriculture [Contract No. 12-34-41-0020 (CA)]; the Monsanto Company, Saint Louis, Missouri; and the Department of Zoology, North Dakota State University, Fargo.

\section{Literature Cited}

Alldredge, J. R. And J. T. Ratti. 1986. Comparison of some statistical techniques for analysis of resource selection. J. Wildl. Manage., 50:157-165.

Allison, P. D. 1995. Survival analysis using the SAS system: a practical guide. SAS Institute, Cary, North Carolina. 292 p.

Byers, C. R., R. K. Steinhorst and P. R. Krausman. 1984. Clarification of a technique for analysis of utilization-availability data. J. Wildl. Manage., 48:1050-1053.

CARROLL, J. P. 1990. Winter and spring survival of radio-tagged gray partridge in North Dakota. J. Wildl. Manage., 54:657-662.

- R. D. CRAWFord AND J. W. Schulz. 1995. Gray partridge winter home range and use of habitat in North Dakota. J. Wildl. Manage., 59:98-103.

Cox, D. R. 1972. Regression models and life tables. J. Royal Stat. Soc., Series B 34:187-220.

Delise, J. M. AND J. A. SAVIDGE. 1997. Avian use and vegetation characteristics of Conservation Reserve Program fields. J. Wildl. Manage., 61:318-325.

Dumke, R. T. And C. M. Pils. 1973. Mortality of radio-tagged pheasants on the Waterloo Wildlife Area. Wis. Dep. Nat. Resour. Tech. Bull. 72.52 p. 
EvARD, J. O. 1996. Winter weather and pheasant populations and harvests in northwestern Wisconsin. Wis. Dep. Nat. Resour. Res. Rep. 171. 17 p.

Gabbert, A. E., A. P. Leif, J. R. Purvis and L. D. Flake. 1999. Survival and habitat use by ring-necked pheasants during two disparate winters in South Dakota. J. Wildl. Manage., 63:711-722.

GATES, J. M. AND J. B. HALE. 1974. Seasonal movement, winter habitat use, and population distribution of an east central Wisconsin pheasant population. Wis. Dept. Nat. Resour. Tech. Bull. 76.55 p.

Gatti, R. C., R. T. Dumke And C. M. Pils. 1989. Habitat use and movements of female ring-necked pheasants during fall and winter. J. Wildl. Manage., 53:462-475.

Greenburg, R. E., S. L. Etter and W. J. Anderson. 1972. Evaluation of proximal primary feather criteria for aging wild pheasants. J. Wildl. Manage., 36:700-705.

Harris, H. J., M. S. Milligan and G. A. Fewless. 1983. Diversity: quantification and ecological evaluation in freshwater marshes. Bio. Conserv., 27:99-110.

Hill, D. A. AND M. W. RidLey. 1987. Sexual segregation in winter, spring dispersal and habitat use in the pheasant (Phasianus colchicus). J. Zool., London, 212:657-688.

Homan, H. J., G. M. LinZ AND W. J. Bleier. 1999. A summary of cattail-spraying operations in North Dakota: 1991-1998. Abstract in Proc. 21 ${ }^{\text {st }}$ Sunflower Res. Workshop, January 14-15, 1999, Fargo, North Dakota.

JARVIS, R. L. AND S. G. SimPSON. 1978. Habitat, survival, productivity, and abundance of pheasants in western Oregon. J. Wildl. Manage., 42:866-874.

Jensen, R. E. 1972. Climate of North Dakota. North Dakota State Univer., Fargo, North Dakota. 48 p.

Johnson, D. H. 1980. The comparison of usage and availability measurements for evaluating resource preference. Ecology, 61:65-71.

KANTRUD, H. A. 1986. Effects of vegetation manipulation on breeding waterfowl in the prairie wetlands-a literature review. U.S. Fish Wildl. Serv. Tech. Rep. 3.15 p.

KaPlan, E. L. AND P. Meier. 1958. Nonparametric estimation from incomplete observations. J. Am. Stat. Assoc., 53:457-481.

KenWARD, R. E. 1987. Wildlife radio tagging: equipment, field techniques, and data analysis. Academic Press, London, U.K. 222 p.

Kie, J. G., J. A. Baldwin and C. J. Evans. 1996. CALHOME: a program for estimating animal home ranges. Wildl. Soc. Bull., 24:342-344.

Kimball, J. W. 1948. Pheasant population characteristics and trends in the Dakotas. Trans. North Am. Wildl. Conf. 13:291-314.

LAIR, H. 1987. Estimating the location of the focal center in red squirrel home ranges. Ecology, 68 : 1092-1101.

Larsen, D. T., P. L. Crookston And L. D. Flake. 1994. Factors associated with ring-necked pheasant use of winter food plots. Wildl. Soc. Bull., 22:620-626.

Lee, J. E., G. C. White, R. A. Garrott, R. M. Bartmann and A. W. Alldredge. 1985. Accessing ( sic) accuracy of a radiotelemetry system for estimating animal locations. J. Wildl. Manage., 49:658663.

LePTICH, D. J. 1992. Winter habitat use by hen pheasants in southern Idaho. J. Wildl. Manage, 56: 376-380.

Linz, G. M., D. C. Blixt, D. L. Bergman and W. J. Bleier. 1996. Responses of red-winged blackbirds, yellow-headed blackbirds and marsh wrens to glyphosate-induced alterations in cattail density. J. Field Ornith., 67:167-176.

Luukkonen, D. R., H. H. Prince and S. R. Winterstein. 1997. Developing survival models from radiotelemetry data for population simulation. Abstract in Managing Natural Resources: integrating ecology and society. 59h Midwest Fish Wildl. Conf., December 7-10, 1997, Milwaukee, Wisconsin.

Marcstrom, V., R. E. Kenward and M. Karlbom. 1989. Survival of ring-necked pheasants with backpacks, necklaces, and leg bands. J. Wildl. Manage., 53:808-810.

McClean, S. A., M. A. Rumble, R. M. King and W. L. Baker. 1998. Evaluation of resource selection methods with different definitions of availability. J. Wildl. Manage., 62:793-801. 
McNay, R. S., J. A. Morgan and F. L. Bunnell. 1994. Characterizing independence of observations on movements of Colombian black-tailed deer. J. Wildl. Manage., 58:422-429.

MoHr, C. O. 1947. Table of equivalent populations of North American small mammals.Am. Midl. Nat., 37:233-249.

Neu, C. W., C. R. Byers And J. M. Peek. 1974. A technique for analysis of utilization-availability data. J. Wildl. Manage., 38:541-545.

Otis, D. L. AND G. C. White. 1999. Autocorrelation of location estimates and the analysis of radiotracking data. J. Wildl. Manage., 63:1039-1044.

Payne, N. F. 1992. Techniques for wildlife habitat management of wetlands. McGraw-Hill, New York, New York. 549 p.

PENROD, B. D. AND J. W. Hill. 1985. Determination of cover characteristics of annual pheasant range. Fed. Aid in Wildl. Restor. Proj. W-81-R. New York Dep. Environ. Conserv., Albany, New York. 30 p.

Perkins, A. L., W. R. Clark, T. Z. Riley and P. A. Vohs. 1997. Effects of landscape and weather on winter survival of ring-necked pheasant hens. J. Wildl. Manage., 61:634-644.

Petersen, L. R. 1979. Ecology of great horned owls and red-tailed hawks in southeastern Wisconsin. Wis. Dept. Nat. Resour. Tech. Bull. 111. 63 p.

Pollock, K. H., S. R. Winterstein, C. M. BunCK AND P. D. Curtis. 1989. Survival analysis in telemetry studies: the staggered entry design. J. Wildl. Manage., 53:7-15.

Ratti, J. T. And E. O. Garton. 1994. Research and experimental design, p. 1-23. In: T. A. Bookhout (ed.). Research and management techniques for wildlife and habitats, 5th ed. The Wildlife Society, Bethesda, Maryland. 740 p.

Riley, T. Z., W. R. Clark, D. E. EwING and P. A. Vohs. 1998. Survival of ring-necked pheasant chicks during brood rearing. J. Wildl. Manage., 62:36-44.

- J. B. WoOley And W. B. Rybarczyk. 1994. Survival of ring-necked pheasants in Iowa. Prairie Nat., 26:143-148.

Roscoe, J. T. AND J. A. Byars. 1971. An investigation of the restraints with respect to sample size commonly imposed on the use of the Chi-square statistic. J. Am. Stat. Assoc., 66:755-759.

SAS InSTITUTE. 1988. SAS/STAT user's guide: Release 6.03 ed. SAS Institute, Cary, North Carolina. 1997. SAS/STAT ${ }^{\varpi}$ Software: changes and enhancements through Release 6.12. SAS Institute, Cary, North Carolina.

Sather-Blair, S. and R. L. Linder. 1980. Pheasant use of South Dakota wetlands during winter. Proc. South Dakota Acad. Sci., 59:147-155.

SCHMitZ, R. A. AND W. R. CLARK. 1999. Survival of ring-necked pheasant hens during spring in relation to landscape features. J. Wildl. Manage., 63:147-154.

SCHOOLEy, R. L. 1994. Annual variation in habitat selection: patterns concealed by pooled data. J. Wildl. Manage., 58:367-374.

SMith, S. A. 1994. Home range and habitat use of ring-necked pheasants (Phasianus colchicus L.) in North Central Maryland. M.Sc. Thesis, Frostburg State University, Frostburg, Maryland. 63 p.

SNYDER, W. D. 1985. Survival of radio-marked hen ring-necked pheasants in Colorado. J. Wildl. Manage., 49:1044-1050.

SOKAL, R. R. AND F. J. ROHLF. 1981. Biometry: the principles and practice of statistics in biological research. 2nd ed. W. H. Freeman and Comp., New York, New York. 859 p.

Stewart, R. E. 1975. Breeding birds of North Dakota. Tri-college Center for Environmental Studies, Fargo, North Dakota. 295 p.

- AND H. A. Kantrud. 1971. Classification of natural ponds and lakes in the glaciated prairie region. U.S. Fish Wildl. Serv. Res. Publ. 92. 57 p.

SwiHART, R. K. AND N. A. SLAdE. 1985. Influence of sampling interval on estimates of home-range size. J. Wildl. Manage., 49:1019-1025.

Tacha, T. C., W. D. Warde and K. P. Burnham. 1982. Use and interpretation of statistics in wildlife journals. Wildl. Soc. Bull., 10:355-362.

Thomas, D. L. And E. J. TAYlor. 1990. Study designs and tests for comparing resource use and availability. J. Wildl. Manage., 54:322-330. 
Trautman, C. G. 1982. History, ecology and management of the ring-necked pheasant in South Dakota. South Dakota Game, Fish, and Parks Dep., Pierre, South Dakota. 118 p.

Wagner, F. H., C. D. Besadny and C. Kabat. 1965. Population ecology and management of Wisconsin pheasants. Wis. Conserv. Dep. Tech. Bull. 34.

WARNER, R. E. AND L. M. DAVID. 1982. Woody habitat and severe winter mortality of ring-necked pheasants in central Illinois. J. Wildl. Manage., 46:923-932.

WELLER, M. W. 1975. Studies of cattail in relation to management for marsh wildlife. Iowa State J. Res., 49:383-412.

White, G. C. And R. A. Garrott. 1984. Portable computer system for field processing biotelemetry triangulation data. Colorado Div. Wildl. Game Infor. Leaf., 110:1-4.

AND — 1990. Analysis of wildlife radio-tracking data. Academic Press, San Diego, California. 383 p.

Whiteside, R. W. ANd F. S. GUthery. 1983. Ring-necked pheasant movements, home ranges, and habitat use in west Texas. J. Wildl. Manage., 47:1097-1104.

Wilson, J. W., R. D. Drobney and D. L. Hallett. 1992. Survival, dispersal, and site fidelity of wild female ring-necked pheasants following translocation. J. Wildl. Manage., 56:79-85.

Wishart, W. 1969. Age determination of pheasants by measurement of proximal primaries. J. Wildl. Manage., 33:714-717.

Wooley, J. B. And W. B. Rybarczyk. 1981. Pheasant population dynamics in southern Iowa. Fed. Aid in Wildl. Restor. Proj. W-115-R. Iowa Conserv. Comm., Des Moines, Iowa. 35 p. 